
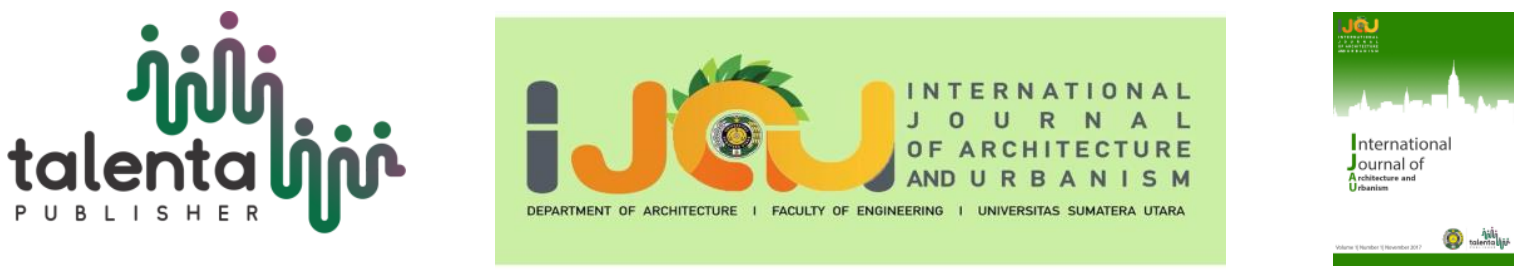

\title{
The Spatial Analysis Urban Structure of Medan Baru Subdistrict
}

\author{
Ronald Yohanes Clinton Sinaga \\ Independent Researcher, Medan. Sumatera Utara. Indonesia
}

\begin{abstract}
A city is a residential area that is physically indicated by a group of houses that dominate the layout and have facilities to support the lives of its citizens independently. In order to optimize urban development, the use of urban space needs to be directed into a city spatial plan consisting of spatial structure and spatial patterns. Data collection methods in this study using observation techniques and data analysis methods in this study using qualitative descriptive. The final result of this research is the condition of the existing spatial structure in Medan Baru District, which has met the service needs in Medan Baru District. However, there must be added facilities that are still lacking in certain areas. The structure of Medan Baru District is close to the concentric concept, the pattern of urban development is in the middle of Medan Baru District as the central area city and spatial structure model of Medan Baru Subdistrict when viewed based on centers service that is approaching the multi-nodal space structure model which consists of one center and several sub-centers and sub-centers which are connected.
\end{abstract}

Keyword: structure, space, Medan Baru district

Received 4 April 2021 | Revised 25 April 2021 | Accepted 1 August 2021

\section{Introduction}

A city is a residential area that is physically shown by a collection of houses that dominate the spatial structure and have facilities to support the lives of its citizens independently. In order to optimize urban development, the use of urban space needs to be directed in the city spatial plan, which consists of space structure and space pattern. By-Law No.26 of 2007 regarding spatial planning purpose of spatial planning intended to achieve safe conditions, comfortable, productivity, and sustainability.

Spatial structure is part of the spatial organization of a city and characterizes certain land uses in the city [1]. Space structure is the arrangement of settlement centers and systems network of infrastructure and facilities serves as a supporter of social activities a hierarchical society with functional relationships. The structure of the city will always change along with the socio-

\footnotetext{
*Corresponding author at: Bunga Rampai Street, Medan, Indonesia

E-mail address: ronaldyohanesclintonsinaga@gmail.com
} 
economic growth of the city and form a certain spatial organization that represents the use of space by humans [2]. The structure is formed based on the spatial distribution of activities [2]. In the Indonesian context, the spatial structure is formed based on the arrangement of settlement centers and a network system of infrastructure and facilities that function as social and economic support activities for the community, which hierarchically have functional relations between settlement centers and network systems of infrastructure and facilities that function as social and economic support activities for the community. Hierarchies have functional relationships [3].

Medan Baru District is one of the sub-districts in Medan City. Medan Baru sub-district is a subdistrict with quite a variety of regional developments. The activity center of Medan Baru Subdistrict, which is relatively located in the middle of the city as one of the growing points, causes urban problems due to the urban spatial structure that is not well organized or inconsistent and by existing regulations. This research was conducted in order to study the spatial structure of the Medan Baru District. This study focuses on the suitability of city activity service centers and urban area infrastructure networks in the city's RT/RW.

\section{$2 \quad$ Literature Review}

Space is defined as a container that includes land space, sea space, air space, including space in the earth as a unitary area where humans and living things carry out their activities and their survival. The spatial structure is an arrangement of residential centers, network systems, and infrastructure and facilities systems that support socio-economic activities, which are hierarchically related functionally.

The structure is an arrangement of settlement centers, network systems, and infrastructure and facilities systems that support socio-economic activities, which are hierarchically related functionally. The urban spatial structure is a description of the city internal activity service center system and the city infrastructure network until the end of the planning period, which is developed to integrate the city area and serve the functions of existing/planned activities in the city area at the city scale, which is an integral part of the regional system provincial, national and even international.

According to Nia K. Pontoh \& Iwan Setiawan (2008), the constituent elements of the urban spatial structure consist of activity centers, functional areas, and road networks [4]. The urban area can be seen as a spatial system, which internally has the elements that form it and its relationship to one another.

Following is the theory that underlies the structure of urban space, namely: Concentration Theory [5] which states that the Central Business District (CBD) is the city center located right in the middle of the city and has a circular shape. It is the center of social, economic, cultural, 
and political life, as well as a zone with a high degree of accessibility in a city. Sectoral Theory [6] states that the Central Business District (CBD) has the same meaning as the Concentric Theory. The Multiple Center Theory [7] states that the Central Business District (CBD) is the city center which is located relatively in the middle of other cells and functions as one of the "growing points". Other theories that underlie the structure of urban space are the Theory of Height of Buildings, The Theory of Sectoral Theory, and the Theory of Historical.

Seen from a service center, the structure of the urban space is divided into two [8], namely monocentric City, Polycentric City. The Town center is the center of all activities of the city, among others, the political, social, cultural, economics, and technology. Meanwhile, a city service sub-center is a center that provides services to the residents and activities of part of the city. It has a hierarchy, function, scale, and service area lower than the city center but higher than the environmental center. The factors that cause the emergence of service centers, namely the location factor, the factor of resource availability, the strength of agglomeration, and the factor of government investment. Urban development is a process of changing urban conditions from one state to another at different times.

Plan for urban spatial structure is a spatial planning framework for the city composed of a constellation of activity centers that are hierarchical and connected by a system of the urban infrastructure network, especially the transportation network. The urban spatial structure plan is formulated based on urban. Spatial planning policies and strategies; development needs and services of the city area to support socio-economic activities. The carrying capacity and tamping capacity of the city area. The provisions of the legislation.

\section{Methodology}

The research method used is descriptive research. Several theories and policies related to the spatial structure can be used as variables in research that can represent the concept of spatial structure. These variables are educational facilities, religious facilities, health facilities, trade facilities and office facilities services, and road networks. This research was conducted in Medan Baru District. Medan Baru sub-district is located in Medan City and has an area of 5.41 $\mathrm{km}^{2}$ with 6 (six) villages consisting of Babura Village, Darat Village, Merdeka Village, Padang Bulan Village, Titi Rante Village, and Petisah Hulu Village (Figure 1). 


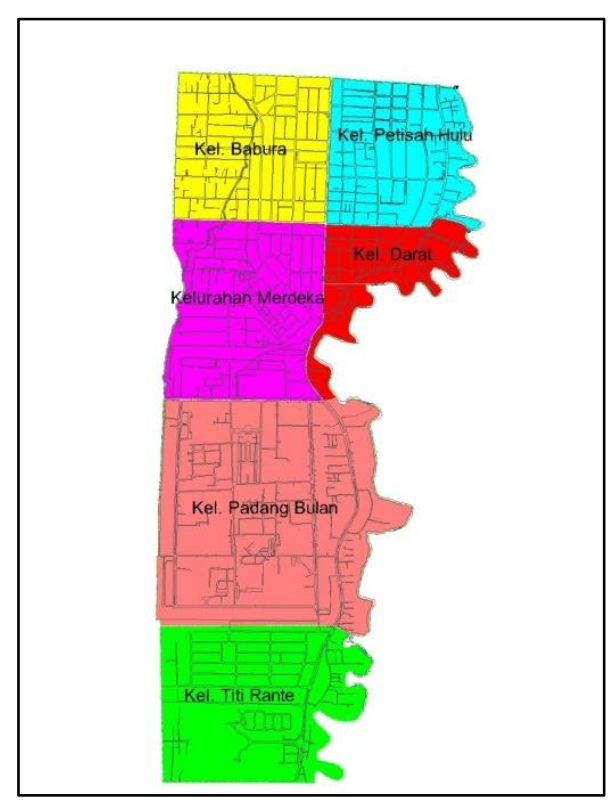

Figure 1 Location of the research area

\section{$4 \quad$ Result and Discussion}

Centers City service centers in Medan Baru Sub-District are Babura Village, Darat Village, Merdeka Village, Padang Bulan Village, Petisah Hulu Village, and Titi Rante Village. This can be seen from the amount of distribution that is concentrated in the area. Even if it is seen from the type and scale of its services, the center of its activities in this area also because the existing facilities are more complete and most of the facilities here serve the scale of city services (Table $1)$.

Table 1 Activities Service Facilities in the District of Medan Baru

\begin{tabular}{lllllll}
\hline Village & Education & Religious & Trade & Health & Office & Total \\
\hline Babura & 5 & 7 & 1 & 5 & 20 & 38 \\
Darat & 3 & 3 & 18 & - & 25 & 49 \\
Merdeka & 4 & 1 & 23 & 3 & 18 & 49 \\
Padang & 7 & 4 & 28 & 1 & 5 & 45 \\
Bulan & & 12 & 30 & 2 & 10 & 70 \\
Petisah & 16 & 17 & 5 & 2 & 4 & 40 \\
Titi Rante & 12 & & & & & \\
\hline
\end{tabular}

From the results of the identification of activity facility services in the area around Medan Baru Subdistrict, it can be seen that the activity service centers are from the distribution of the facilities. In addition, determining the service center for its activities is based on the type and scale of services of the said activity service facilities. In determining the activity service center, 
an overlay analysis technique is used, namely by combining the distribution maps of the facilities manually. From the results of the analysis technique, it can be seen that those that can be used as service centers for primary activities are in Merdeka, Darat, Petisah Hulu, and Padang Bulan villages, this can be seen from the number of distributions that are centered in these villages and because the existing facilities are more complete and mostly The existing facilities in this sub-district serve all sub-districts.

The road network system in The Medan Baru sub-district has connect service centers with other centers. All Kelurahan in the Medan Baru sub-district can be reached. The road network development includes plans to build a new road network and improve the function of the road network (Figure 2).

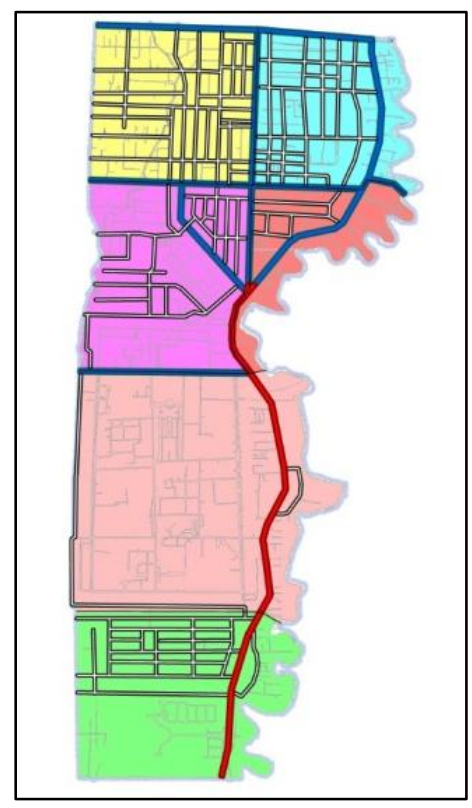

Figure 2 Road Network Development

Provincial roads, as primary collector roads, cover the road network part of the Jamin GintingIskandar Muda road. This road connects the Titi Rante sub-district-Padang Bulan sub-districtMerdeka sub-district-Darat village-Babura sub-district-Petisah Hulu sub-district. The city road is a secondary collector road, covering the Iskandar Muda road section and the Patimura road section. This road connects Merdeka and Babura sub-districts, then this road connects DaratPetisah Hulu sub-districts. The primary arterial road covers the road network, which is part of Dr. Mansur, and Abdulah Lubis Street. The primary arterial road is Dr. Mansur road, which divides Village Padang Bulan and Village Merdeka. The primary artery road of Abdulah Lubis is the border between Merdeka and Babura villages.

Compared with the existing structural theory, the service zone of the Medan Baru sub-district is closer to the concentric theory. Concentric Theory (Burgess, 1925) states that the city center area is a city center located in the middle of the city and has a circular shape which is the center 
of social, economic, cultural, and political life, and is a zone with a high degree of accessibility in a city (Figure 3).

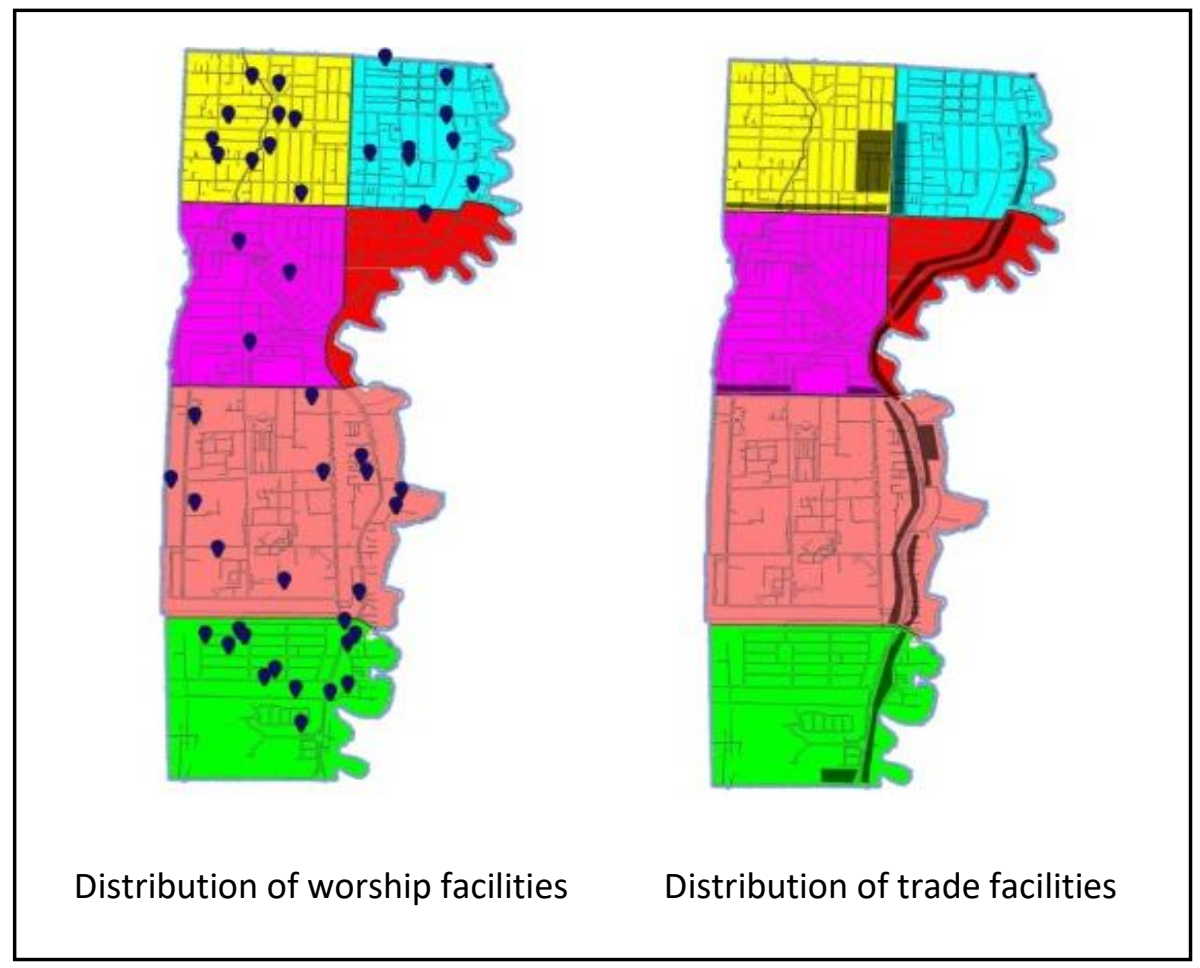

Figure 3 Analysis of research area

As with the Medan Baru sub-district, whose activity service centers are located in the middle of the city, to be precise, Petisah Hulu sub-district, Merdeka village, Darat village, and Padang Bulan village. The central area of activity in this area is developing as the main center of regional growth in Medan Baru District. For the main center of urban activities in this area, facilities such as trade and services, offices, worship, health, and education are available in this area which functions as a city service center for urban service sub-centers and environmental service centers located in the surrounding subdistricts located around the service center area of this activity, such as Titi Rante and Babura villages (Figure 4). For the spatial structure model seen based on its service centers, Medan Baru District approaches the Multi Nodal spatial structure model, which consists of one center and several sub-centers and sub-centers which are connected. Medan Baru District service centers, in this case, Petisah Hulu Village and Merdeka Village. 


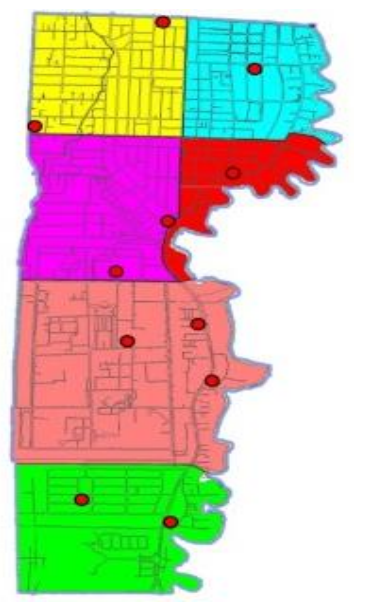

Distribution of health facilities

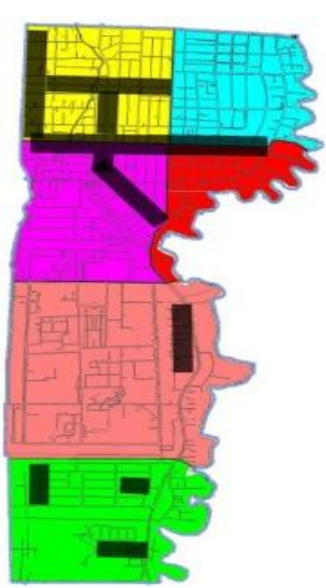

Distribution of office facilities

Figure 4 Analysis of research area

\section{Conclusion}

From the conclusion of the spatial structure of the Medan Baru sub-district, there are several aspects that form space, namely population, city activity service centers, and urban area infrastructure networks. The structure of service activities in Medan Baru Subdistrict, there is a primary service structure in Medan Baru Subdistrict, located in Merdeka Village, Darat Village, Petisah Hulu Village, and Padang Bulan Village and functions to meet the service scale needs of the Medan Baru District.

Sub-city service centers or secondary service structures are located in Titi Rante and Babura sub-districts, which function to help the primary service structure meet the needs of the Medan Baru District. The urban structure of Medan Baru Subdistrict is close to a concentric concept; the pattern of city development is in the middle of Medan Baru Subdistrict as the downtown area. The spatial structure model of Medan Baru Subdistrict, when viewed based on its service centers, is close to a multi-nodal spatial structure model, which consists of one center and several sub-centers and sub-centers, which are connected.

\section{Acknowledgment}

As for the suggestions that can be given based on the research that has been done is to meet the needs of city services in Medan Baru District, the government needs to encourage the government to meet these needs by building adequate facilities and how the community and government maintain each other's service facilities that have been built. 


\section{REFERENCES}

[1] J. Sohn, "Are commuting patterns a good indicator of urban spatial structure?," Journal of transport geography, vol. 13, no. 4, pp. 306-317, 2005.

[2] C. Borrego, H. Martins, O. Tchepel, L. Salmim, A. Monteiro dan A. I. Miranda, "How urban structure can affect city sustainability from an air quality perspective," Environmental modelling \& software, vol. 21, no. 4, pp. 460-467, 2006.

[3] “Undang-Undang Penataan Ruang No. 26 Tahun 2007”.

[4] K. P. Nia dan I. Setiawan, Pengantar Perencanaan Kota, Bandung: ITB, 2008.

[5] M. M. Perron, K. T. Ho, M. G. Cantwell, R. M. Burgess dan M. C. Pelletier, "Effects of triclosan on marine benthic and epibenthic organisms," Environmental toxicology and chemistry, vol. 31, no. 8, pp. 1961-1866, 2012.

[6] R. Banai, "Concentric Zone Theory," The Wiley Blackwell Encyclopedia of Urban and Regional Studies, pp. 1-6, 2019.

[7] R. Ananya, "The 21st-century metropolis: New geographies of theory," Regional Studies, vol. 43, no. 6, pp. 819-830, 2009.

[8] C. McFarlane, "The city as assemblage: dwelling and urban space," Environment and Planning D: society and space, vol. 29, no. 4, pp. 649-671, 2011. 